University of Rhode Island

DigitalCommons@URI

The Rhode Island Current Conditions Index

Economics

6-2014

\title{
Rhode Island Current Conditions Index -- June 2014
}

Leonard Lardaro

University of Rhode Island, lardaro@uri.edu

Follow this and additional works at: https://digitalcommons.uri.edu/ricci

Part of the Econometrics Commons

Terms of Use

All rights reserved under copyright.

\section{Recommended Citation}

Lardaro, Leonard, "Rhode Island Current Conditions Index -- June 2014" (2014). The Rhode Island Current Conditions Index. Paper 115.

https://digitalcommons.uri.edu/ricci/115

This Article is brought to you for free and open access by the Economics at DigitalCommons@URI. It has been accepted for inclusion in The Rhode Island Current Conditions Index by an authorized administrator of DigitalCommons@URI.For more information, please contact digitalcommons-group@uri.edu. 


\title{
CURRENT CONDITIONS
}

\section{LEONARD LARDARO, URI}

\author{
Available Online: http:/ / www .Ilardaro.com/ current.htm \\ Blog: http:/ / rieconomy.blogspot.com
}

VOL XXI

NUMBER 7

JUN 2014

Just when it appeared that Rhode Island's economy was beginning to re-accelerate, bringing back memories of late 2012, along comes June's data that abruptly shatters that notion and then some. The June Current Conditions Index value fell all the way back to its neutral value of 50 , as only six of the twelve $\mathrm{CCl}$ indicators improved. Worse yet, April's value that had been 58 has been revised down to 50 as well. Not exactly life in the fast lane!

To say that Rhode Island's overall performance in 2014 has been somewhat disappointing has now become an understatement. Not only did we never get the post-winter bounce we were hoping for, even the good-weather months are proving to be very disappointing. What I find perplexing about Rhode Island's most recent performance is that in spite of an improving national economy, we continue to flounder

Perhaps the most pressing issue now is whether Rhode Island has begun to decouple from the accelerating national economy. Apparently, Rhode Island's negatives are finally catching up to its positives, increasingly diminishing overall momentum. This is part of the reason why Rhode Island has been unable to reduce its Unemployment Rate to a level that would end its prolonged stretch as the state with the highest jobless rate. Think about this for a moment - not only does Rhode Island lag in terms of its relative performance, if recent trends continue, it will begin to lag in terms of its absolute performance as well. I now characterize

\begin{tabular}{|c|c|}
\hline \multicolumn{2}{|c|}{ CCI Indicators - $\%$ Change } \\
\hline Government Employment & -0.3 \\
\hline US Consumer Sentiment & -1.6 \\
\hline Single-Unit Permits & 23.7 \\
\hline Retail Sales & 3.4 \\
\hline Employment Services Jobs & -4.1 \\
\hline Priv. Serv-Prod Employment & 1.2 \\
\hline Total Manufacturing Hours & 4.3 \\
\hline Manufacturing Wage & -2.3 \\
\hline Labor Force & $0.5 Y$ \\
\hline Benefit Exhaustions & 10.0 \\
\hline New Claims & 21.8 \\
\hline Unemployment & $-1.6 Y$ \\
\hline
\end{tabular}

Rhode Island's performance as moving from precarious to tenuous, with June marking the eleventh consecutive month where the $\mathrm{CCl}$ has failed to beat its year-earlier value.

For June, only two of the five leading indicators contained within the Current Conditions Index improved, although both did so at healthy rates. Single-Unit Permits, which reflect new home construction, turned in yet another strong performance in June, rising by 23.7 percent relative to last June. Total Manufacturing
Hours, which measures strength in our manufacturing sector, rose sharply again in June $(+4.3 \%)$, as both the length of the workweek rose and manufacturing employment increased. Oddly, in spite of this continuing manufacturing momentum, the Manufacturing Wage actually declined for a fourth consecutive time in June, by 2.3 percent.

US Consumer Sentiment fell for the second consecutive month $(-1.6 \%)$ following a string of five consecutive increases. Employment Service Jobs, which includes temporary employment, and is a prerequisite to employment growth, declined sharply in June, by 4.1 percent, its seventh consecutive decline. I continue to view changes in this indicator somewhat suspiciously. The biggest surprises for June, which contributed a great deal to the CCI's neutral value of 50, were increases in both New Claims for Unemployment Insurance, the timeliest measure of layoffs, and Benefit Exhaustions, which reflects longer -term unemployment. Of these, New Claims, which is a leading indicator, rose at an alarming rate, 21.8 percent relative to last June. It is not clear whether the recent improvements in this indicator will prove to be sustainable. Benefit Exhaustions increased by 10 percent relative to a year ago, following two consecutive months of double-digit improvement.

Retail Sales was one of the few bright spots for J une, rising by 3.4 percent compared to a year ago. This indicator has now improved for six of the last eight months. Private ServiceProducing Employment rose by 1.2 percent in June, slightly slower than its May growth. Government Employment fell once again, declining by 0.3 percent versus last June. Finally, Rhode Island's Labor Force actually rose again June, while our Unemployment Rate fell to 7.9 , but remained \# 1 .

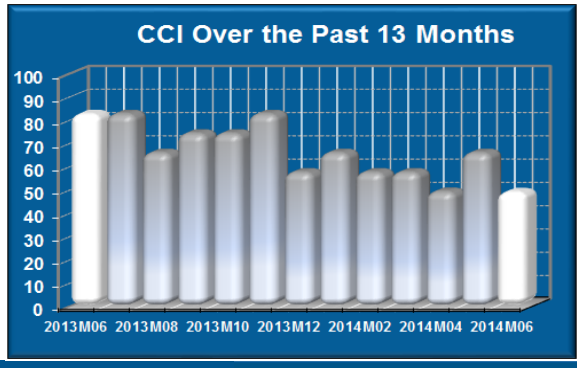
DLT J UN
Employment
$(S A, Y / Y)$

\section{Gain} 7,600 Loss 2,900

\section{THE BOTTOM LINE}

If Rhode Island's economic momentum is hanging on by a finger nail, apparently that finger nail is its goods-producing sector. Who would have ever though that our state's goods-producing sector (housing and manufacturing) would be carrying us at a point in time when we have been a post-manufacturing economy for so long (since late 1987)? While I am hoping that the recent 50 values prove to be aberrations, the best indication of our future direction will be determined by our ability to exceed year-earlier $\mathrm{CCl}$ values. Since our elected officials have done virtually nothing to reinvent our state's economy, all we can do for now is keep our fingers crossed.

\begin{tabular}{|l|l|l|l|l|l|l|l|l|l|l|l|l|l|}
\hline & Jan & Feb & Mar & Apr & May & J un & J ul & Aug & Sep & Oct & Nov & Dec \\
\hline \multirow{2}{*}{2013} & 75 & 67 & 83 & $83 \uparrow$ & $75 \downarrow$ & $83 \uparrow$ & 83 & 67 & $75 \uparrow$ & 75 & $83 \uparrow$ & $58 \downarrow$ \\
\hline & 2014 & $67 \downarrow$ & 58 & 58 & $50 \downarrow$ & 67 & 50 & & & & & & \\
\hline
\end{tabular}

$\because D$ 口 